\title{
Geography, Drinking Water Chemistry, Pesticides and Herbicides and the Etiology of Parkinson's Disease
}

\author{
A.H. Rajput, Ryan J. Uitti, W. Stern, W. Laverty, K. O'Donnell, \\ D. O'Donnell, W.K. Yuen and A. Dua
}

\begin{abstract}
In 1984 we made the first observation of a correlation between early age exposure to rural environment (and drinking well water) and development of idiopathic Parkinson's disease (IPD). ${ }^{13}$ These findings were subsequently confirmed elsewhere (Barbeau, $1985 ; ;^{25}$ Tanner, $1985^{26}$ ). Analysis of all early age onset IPD (EPD) cases born and raised in Saskatchewan revealed that 20 of 22 had exclusively rural exposure during the first 15 years of life. This distribution was significantly different from the general population $(p=0.0141)$. Further study of the EPD group included sampling and metal analysis of childhood sources of drinking water in 18 cases and 36 age and sex-matched controls. Water collected from the two groups was analyzed for 23 metals (including 7 elements implicated in the etiology of IPD). There was no difference in the metal composition of the water between the two groups ${ }^{17}$ Finally, a review of herbicide and pesticide use in Saskatchewan agriculture was undertaken to determine if there was an increased incidence of EPD following utilization of any particular chemical. No increase was found in the incidence of EPD with the introduction of any pesticide or herbicide, including Paraquat, for agricultural use. We conclude that there is a strong correlation between early age rural environmental exposure and development of IPD. We believe well water is a likely vehicle for the causal agent, but neither water metal concentration nor any of the herbicides and pesticides used in Saskatchewan agriculture are related to the cause.
\end{abstract}

RÉSUMÉ: Etiologie de la maladie de Parkinson et site géographique, qualité chimique de l'eau potable, pesticides et herbicides. En 1984, nous avons rapporté pour la première fois l'obervation d'une corrélation entre une exposition à un environnement rural dans le jeune âge (et l'absorption d'eau provenant de puits) et le développement de la maladie de Parkinson idiopathique (MPI).$^{13}$ Ces constatations ont été confirmées subséquemment ailleurs (Barbeau, 1985; ${ }^{25}$ Tanner, $1985^{26}$ ). Une analyse de tous les cas de MPI à début précoce qui sont nés et ont été élevés en Saskatchewan a révélé que 20 de ces 22 cas ont été exposés à un environnement exclusivement rural pendant les 15 premières années de leur vie. Cette distribution était significativement différente de la population en général $(p=0.0141)$. Une étude plus poussée du groupe de MPI comportait un échantillonnage des sources d'approvisionnement en eau potable utilisées dans leur enfance chez 18 des cas ainsi que chez 36 contrôles appariés pour l'âge et le sexe et l'analyse des métaux contenus dans ces échantillons, soit 23 métaux dont 7 éléments déjà mis en cause dans l'étiologie de la MPI. Il $n$ 'existait pas de différence dans la composition en métaux de l'eau entre les deux groupes. ${ }^{17}$ Finalement nous avons entrepris une revue de l'utilisation des herbicides et des pesticides en agriculture en Saskatchewan pour déterminer s'il y avait eu une augmentation de l'incidence de la MPI à la suite de l'utilisation d'un produit chimique en particulier. Nous n'avons trouvé aucune augmentation de l'incidence de la MPI avec l'introduction d'un pesticide ou herbicide particulier, incluant le Paraquat, pour utilisation agricole. Nous concluons qu'il y a une forte corrélation entre une exposition à un milieu environnemental rural dans le jeune âge et le développement de la MPI. Nous croyons que l'eau provenant de puits est un véhicule possible de l'agent causal, mais ni la concentration de métaux dans l'eau, ni aucun des herbicides et des pesticides utilisés en agriculture en Saskatchewan ne sont reliés à la cause de cette maladie.

Can. J. Neurol. Sci. 1987; 14:414-418

The most common form of Parkinson syndrome (PS) is idiopathic Parkinson's disease (IPD), ${ }^{1}$ which begins insidiously with clinical features becoming recognizable many years after the onset. ${ }^{2}$ For a long time there was debate over whether the cause of IPD was genetic or environmental. The most widely publicized environmental hypothesis was advanced by Poskanzer and Schwab. ${ }^{3}$ They postulated that only those exposed to the von Economo encephalitis agent (1918-early 1930's) would develop Parkinson's disease. If this hypothesis were true, IPD would become extinct when all exposed individuals had passed away, as no new epidemic has occurred since the 1930's. The cohort hypothesis for IPD was repeatedly challenged and recent epidemiological studies have conclusively refuted it.' The controversy over genetic etiology as well, has been satisfactorily resolved by recent studies of twins. ${ }^{4.5}$ The recent discovery that 1 -methyl-4-phenyl-1,2,3,6-tetrahydropyridine (MPTP) is 
destructive to the substantia nigra thus resulting in parkinsonism, ${ }^{6.7}$ is a major contribution and further favours an environmental source as the cause of IPD.

We became interested in epidemiological studies in the late 1970 's in an effort to examine the cohort hypothesis ${ }^{3}$ and the conflicting reports on the effects of levodopa therapy in the parkinsonian population.

In an effort to elucidate the cause of IPD, smoking patterns and 89 other illnesses in parkinsonian patients were compared with age and sex matched controls in the Rochester, Minnesota population. ${ }^{8.9 .10 .11}$ Analysis of risk factors revealed that only psychoneurosis and psychosomatic illnesses diagnosed prior to the clinical onset represented a significant risk (adjusted $R R=2.2$; $p=0.008 ; 95 \% \mathrm{CI}=1.2-4.1)$ for IPD. ${ }^{11}$ Since the pathogenesis of psychoneurosis and psychosomatic illnesses is not well understood, this information, at present time, cannot be effectively utilized in determining the cause of IPD.

Because IPD usually manifests around age 60 years, study of all possible environmental factors prior to clinical onset is nearly impossible. We decided to search for alternative methods as would allow satisfactory evaluation of major environmental factors in these cases. In 1983 we identified all IPD cases whose symptomatology manifested before 40th birthday (EPD) and were seen in the parkinson clinic, University Hospital, Saskatoon. ${ }^{12}$ Two of these cases were verified at autopsy to have Lewy body Parkinson's disease. We assumed that EPD represented an early and/or more extensive exposure to IPDproducing factor(s) and elected to evaluate the environmental factors in these cases.

\section{Materials AND METHODS}

Our studies can be divided into four phases. Phase I included study of all EPD cases in our parkinson clinic. Information was obtained concerning: sex, year of birth, racial background, age of clinical onset, occupation, prior history of encephalitis, major tranquilizer usage, family history of parkinsonism or other neurological disorders, the residence of the family when the patient was born, residence of the patient up to 15th birthday and the source of drinking water during first 15 years of life. These observations were reported in $1984 .^{13}$

Phase II involved study of all EPD cases in the province and was reported in $1986 . .^{14}$

Phase III dealt with study of drinking water in EPD cases and controls. The source of childhood drinking water was identified from the patient, family, or others who knew the patient, in 18 cases who were born and raised in Saskatchewan. For each case, we selected two age and sex matched controls, who had grown up in Saskatchewan, and who did not suffer from a chronic neurological or systemic disease or any other illness believed to be related to a toxicity or deficiency state. The exact location of the source of drinking water in each patient and each control was identified by a qualified land surveyor (D.O.). For each well, the general topography of the area, the depth and the type of the well were noted. Unusual water consumption habits, such as use of special water containers, were recorded in cases and in controls. Where the original well was no longer functional, the nearest well within a $5 \mathrm{~km}$ radius of the original well was used as the substitute source. The original source of water was available for only 7 EPD cases. The water was collected in special plastic bottles, utilized for that purpose by the Saskatchewan Research Council (SRC) laboratory in Saskatoon. Analysis for 23 metals: silver (Ag), aluminum $(\mathrm{Al})$, barium $(\mathrm{Ba})$, boron $(\mathrm{B})$, beryllium $(\mathrm{Be})$, calcium $(\mathrm{Ca})$, cadmium $(\mathrm{Cd})$, cobalt $(\mathrm{Co})$, chromium $(\mathrm{Cr})$, copper $(\mathrm{Cu})$, iron $(\mathrm{Fe})$, potassium $(\mathrm{K})$, magnesium $(\mathrm{Mg})$, manganese $(\mathrm{Mn})$, molybdenum $(\mathrm{Mo})$, sodium $(\mathrm{Na})$, nickel $(\mathrm{Ni})$, phosphorus $(\mathrm{P})$, lead $(\mathrm{Pb})$, titanium $(\mathrm{Ti})$, vanadium $(\mathrm{V})$, tungsten $(\mathrm{W})$, and zinc (Zn) were performed at the SRClaboratory without prior knowledge of the source of the water sample. Methods used for chemical analysis were similar to those described elsewhere. ${ }^{15.16}$

Phase IV consisted of evaluating the relationship between clinical onset of EPD and the use of pesticides and herbicides in Saskatchewan agriculture. This information was obtained by one of us (A.D.) from provincial agriculture records and from personal contacts with experts in the field at the University of Saskatchewan. The onset of parkinsonian symptomatology, in each case, was then correlated with the use of paraquat, and other major herbicides and pesticides, in the province.

\section{RESULTS}

During phase I we found 21 EPD cases. Six of these were excluded, as five were raised outside of Saskatchewan and the other, a native Indian, although born and raised in Saskatchewan, because we could not definitely identify the place of birth and childhood residence. All the remaining 15 cases were born and raised in rural Saskatchewan communities with populations of 140 or less. Statistical analysis indicated a strong correlation between rural childhood residence and EPD. Each of these patients had exclusively consumed well water during childhood and we suggested that the drinking water was related to the causal agent of IPD. ${ }^{13}$

Phase II involved analysis of environmental factors in all EPD cases born and raised in the province. ${ }^{14}$ Twenty-one such cases were identified. Nineteen of these had spent the first 15 years exclusively in rural, one exclusively in urban and one about half of the time in rural and half in urban environments. Total provincial population and urban and rural distribution corresponding to the first 15 years of life of all EPD cases were tabulated. Statistical calculations using the binomial distribution, even when the most conservative possible pattern of environmental exposure was postulated, revealed a significant correlation between rural residence and $\operatorname{EPD}(p=0.0154)$. The mothers of two EPD patients also suffered from IPD. In one case, the mother had onset at age 46 , occurring several years before the onset in the patient, while in the other case, the mother had onset at age 55, several years after the patient. Major rural and urban environmental factors are considered in Table 1. There

\begin{tabular}{|c|c|c|}
\hline & Rural & Urban \\
\hline $\begin{array}{l}\text { (1) Air Quality } \\
\text { (2) Industry and } \\
\text { Occupation }\end{array}$ & $\begin{array}{l}\text { No Pollution } \\
\text { Agriculture } \\
\text { Cattle \& related } \\
\text { Potash mining } \\
\text { (recent) } \\
\text { Uranium mine } \\
\quad \text { (North) }\end{array}$ & $\begin{array}{l}\text { No Pollution } \\
\text { Government } \\
\text { University } \\
\text { Trade } \\
\text { Minimal manufact. } \\
\text { (No heavy indust.) }\end{array}$ \\
\hline (3) Food Source & $\begin{array}{l}\text { Farm Products } \\
\text { Vegetables ( } 3-4 \text { mos) }\end{array}$ & $\begin{array}{l}\text { Food stores } \\
\text { (some garden Veg) }\end{array}$ \\
\hline (4) Water source & Well & $\begin{array}{l}\text { Central running } \\
\text { water }\end{array}$ \\
\hline (5) Health care & Universal since 1962 & $\begin{array}{l}\text { More advanced } \\
\text { than rural }\end{array}$ \\
\hline
\end{tabular}


was no ethnic or racial predilection to Parkinson's disease. It was also concluded that the childhood use of well water significantly correlated with EPD $(p=0.003) .{ }^{14}$ To date, we have identified 22 EPD cases from Saskatchewan, 21/22 used exclusively well water in childhood and 20/22 were raised in rural environments (Figure 1). Based on the rural-urban provincial population distribution, the probability of a random sample individual having rural exposure during the 59 -year study period is 0.684 . The probability that 21 of 22 cases would have rural environmental exposure is $p=0.0024$ and the probability that 20 of 22 would have rural exposure is $p=0.0141$ (Table 2). Each of these values is statistically significant, thus indicating a strong correlation between rural residence and IPD. The proba-

\section{IDIOPATHIC PARKINSON'S DISEASE}

\author{
ONSET BEFORE 40TH \\ BIRTHDAY
}

SASKATCHEWAN, CANADA
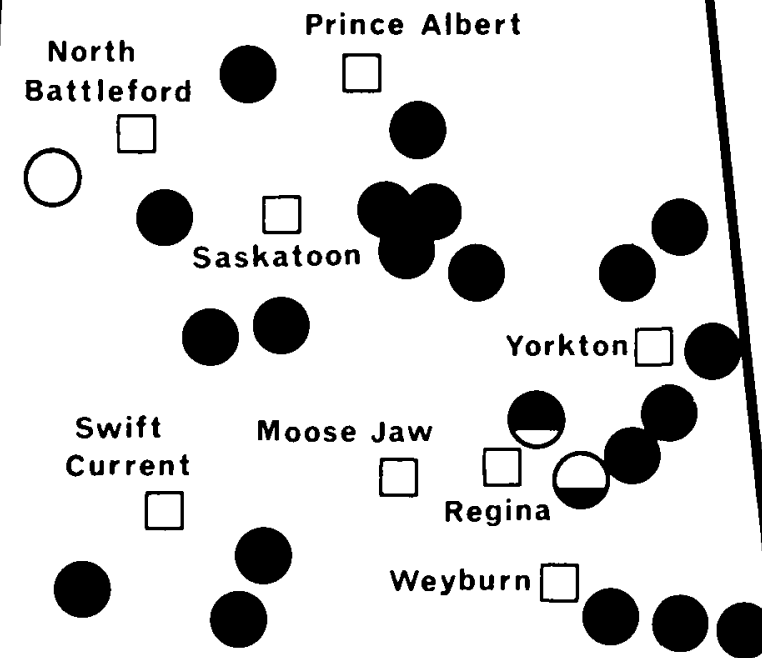

Figure 1 - Each filled circle represents a rural community where a patient spent the majority of childhood. The open circle represents the urban communitv where one case spent childhood. Partially filled circles represent the residence of one case who spent part of childhood in a rural and part in an urban community. bility of $21 / 22$ cases having used well water is $p=0.0024$ (Table 2) and also indicates a strong correlation with IPD. Analysis of occupations in the 22 cases (Table 3 ) showed no correlation between IPD and any life style.

During Phase III the metal composition of the drinking water samples from 18 patient and 36 matched control sources were compared. The mean metal concentrations for 23 metals - Ag, $\mathrm{Al}, \mathrm{B}, \mathrm{Ba}, \mathrm{Be}, \mathrm{Ca}, \mathrm{Cd}, \mathrm{Co}, \mathrm{Cr}, \mathrm{Cu}, \mathrm{Fe}, \mathrm{K}, \mathrm{Mg}, \mathrm{Mn}, \mathrm{Mo}, \mathrm{Na}, \mathrm{Ni}$, $\mathrm{P}, \mathrm{Pb}, \mathrm{Ti}, \mathrm{V}, \mathrm{W}$, and $\mathrm{Zn}$ were not different between the two groups. When the comparison was limited to the seven samples obtained from original wells used by patients and 14 matched controls, again, no difference was noted. ${ }^{17}$

Phase IV was intended to evaluate the use of paraquat and other herbicides and pesticides in Saskatchewan agriculture and the incidence of EPD historically. Table 4 shows clinical onset of EPD cases and milestones in the use of major chemicals in Saskatchewan agriculture. ${ }^{18.19} \mathrm{Six}$ patients had their onset after 1969, when paraquat was first utilized in provincial agriculture, and only two of these were farmers. No increase in incidence of EPD (approximately one case every two years) is seen to coincide with the use of any agricultural chemical in the province (Table 4).

\section{Discussion}

While the argument for an environmental cause of IPD has been slowly strengthening in recent years, strategies to further unravel the mystery have been limited. Simultaneous studies of several factors or evaluation of a single factor as the possible etiology of IPD have been unrewarding. ${ }^{14.20}$ The contention that smoking prevented subsequent development of IPD has now been refuted by several workers. ${ }^{9.10 .11 .21 .22}$

Parkinsonism due to MPTP, has provided a valuable experimental model and recently eosinophilic inclusions have been reported in older monkeys receiving a low dose of MPTP. ${ }^{23}$ Yet, even if one assumes that MPTP or a related substance is responsible for IPD, it remains to be determined where and how such an agent gains access into the human body.

Table 2: Provincial population rural - urban Environment exposure during 59 years (1904 - 1962)

\begin{tabular}{lcc}
\hline \hline $\begin{array}{c}\text { Total } \\
\text { Per. years }\end{array}$ & $\begin{array}{c}\text { Rural } \\
\text { Per. years }\end{array}$ & $\begin{array}{c}\text { Urban } \\
\text { Per. years }\end{array}$ \\
\hline $43,458,168$ & $29,739,477$ & 13.718 .691 \\
& $(68.4 \%)$ & $(31.6 \%)$ \\
EPD cases 22 & $20+1^{*}$ & $1+1^{*}$ \\
Random sample rural exposure, Probability $=0.654$ & \\
21/22 Rural Exposure & $P=0.0024$ & \\
well water & $P=0.0024$ & \\
20/22 Rural exposure & $\mathrm{P}=0.0141$ & \\
\hline
\end{tabular}

\begin{tabular}{lc}
\hline Table 3: Occupation in 22 EPD Cases & \\
\hline \hline M - 14 & F - 8 \\
\hline Farming & 8 \\
Housewife & 6 \\
Sales person, & 5 \\
Teacher-Nun, & 3 \\
Manual Labor $)$ & \\
Unemployed & \\
\hline
\end{tabular}


In 1984 for the first time we identified a geographic area (rural Saskatchewan) that predisposed to IPD.$^{13}$ We postulated that the drinking water utilized in childhood was the likely source of the causal agent. Having done so, we awaited verification of our findings. One year later, when we reported our extended study, ${ }^{24}$ two other reports ${ }^{25.26}$ confirmed our observations. Table 5 shows a summary of the recent environmentally related epidemiological studies in IPD. A careful review of the literature indicates a higher prevalence rate of IPD in rural agricultural communities in some other parts of world as well, ${ }^{27}$ although those authors made no such claim.

Nine different metals: $\mathrm{Al}, \mathrm{As}, \mathrm{Ca}, \mathrm{Cu}, \mathrm{Fe}, \mathrm{Mn}, \mathrm{Mg}, \mathrm{Hg}$ and $\mathrm{Zn}$ have been implicated in parkinsonism. ${ }^{28}$ Our preliminary studies in IPD and control brains indicated some differences in the metal concentrations between the two groups. ${ }^{29}$ Parkinson's disease is seen in all geographic areas and in all societies (some frequently boil their drinking water). Therefore, as the first step, we evaluated metals, rather than organic compounds, in drinking water. We found no difference in metal concentrations in the drinking water of patients and controls. It should be noted that we did not test for two metals (As and $\mathrm{Hg}$ ), implicated in the etiology of IPD, in our water samples.
Following the discovery that MPTP produced parkinsonism, Barbeau ${ }^{30}$ suggested that paraquat, with a chemical structure resembling MPTP, might be the cause of IPD. One year later, Barbeau and Roy ${ }^{25}$ reported that prevalence of parkinsonism was higher in those rural areas of Quebec that specialized in market gardening and pulp milling - areas utilizing herbicides and pesticides. They suggested that those with a genetic predisposition, when exposed to herbicides, like paraquat, developed Parkinson's disease. ${ }^{25}$ Bocchetta and Corsini ${ }^{31}$ have recently reported two patients believed to suffer from paraquat induced parkinsonism. ${ }^{31}$ On the other hand, Koller, ${ }^{32}$ who reviewed historical, epidemiological, pharmacological, and experimental data, concluded that there was no definitive evidence that paraquat was the cause of IPD. Considering the pattern presented in Table 4, it is obvious that there has been no change in the frequency of incidence cases in Saskatchewan to coincide with paraquat or any herbicide or pesticide usage in the province.

Information on epidemiological studies that have major social and economic implications to the public at large should be handled with caution. Our first report (1984), ${ }^{13}$ suggesting that the drinking (well) water was the likely source of IPD, received considerable national and provincial news coverage. We were

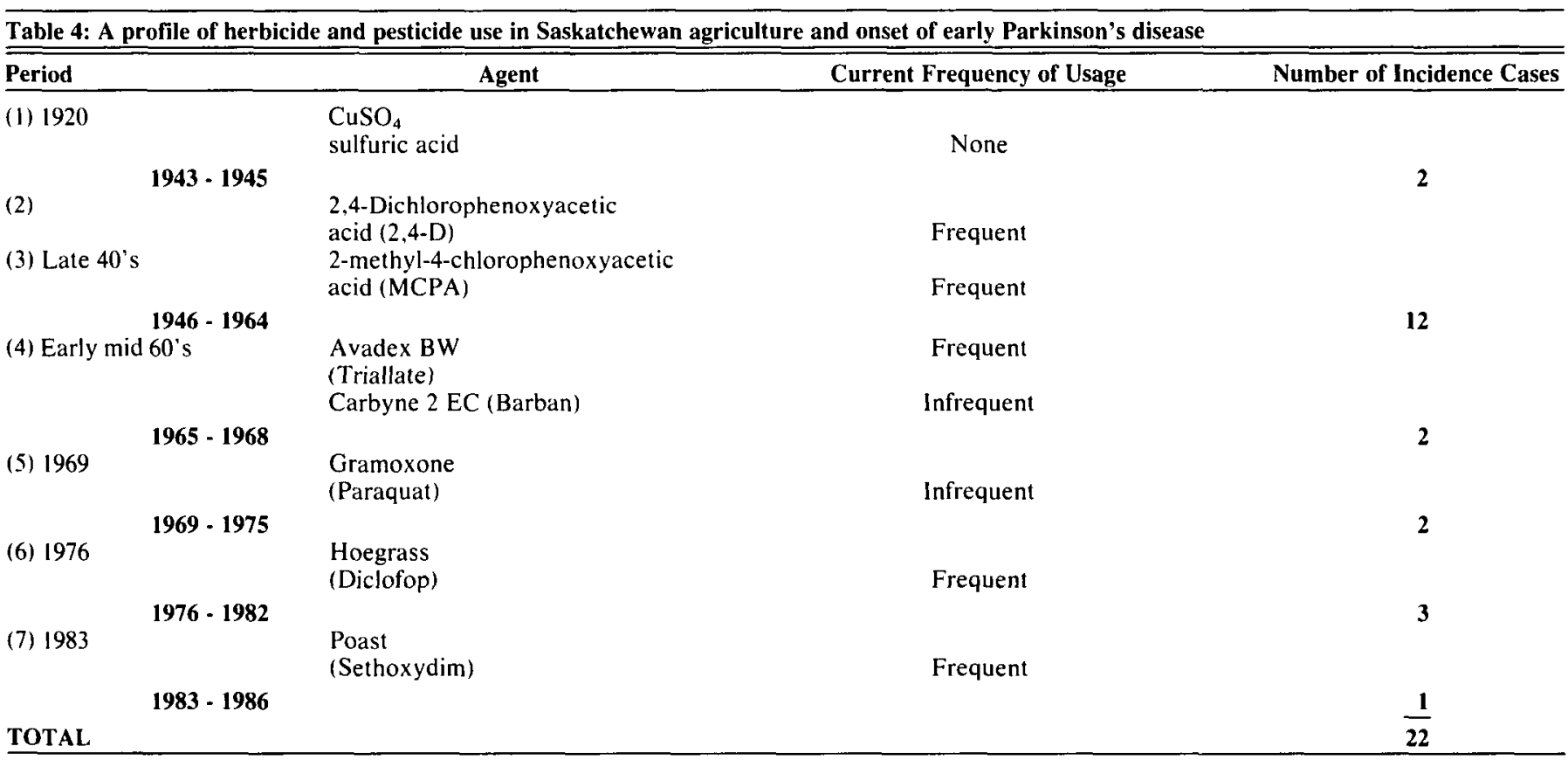

\begin{tabular}{|c|c|c|c|c|}
\hline Year & Authors & $\begin{array}{c}\text { Sources of } \\
\text { Patients evaluated }\end{array}$ & Geographic Disposition & Suggested source of cause \\
\hline 1984 & Rajput et al ${ }^{13}$ & Parkinson Clinic & $\begin{array}{l}\text { Rural Saskatchewan (early onset } \\
\text { of idiopathic Parkinson Disease) }\end{array}$ & Drinking well water \\
\hline 1985 & Rajput et $\mathrm{al}^{24}$ & Parkinson Clinic & Rural Saskatchewan & Drinking well water \\
\hline 1985 & C. Tanner ${ }^{26}$ & Parkinson Clinic & $\begin{array}{l}\text { Rural - Illinois, Indiana, Iowa, } \\
\text { Wisconsin. Michigan }\end{array}$ & Drinking well water \\
\hline 1986 & C. Tanner ${ }^{33}$ & $\begin{array}{l}\text { United Parkinson } \\
\text { Foundation Newsletter survey }\end{array}$ & $\begin{array}{l}\text { Those using well water have early } \\
\text { age of onset }\end{array}$ & Drinking well water \\
\hline 1986 & Rajput et al ${ }^{14}$ & Province of Saskatchewan & Rural Saskatchewan communities & Drinking well water \\
\hline
\end{tabular}


asked if the rural communities should stop using local well water for safety reasons. Such a recommendation, in the absence of conclusive evidence, would not be justified, and would have a high social and economic cost to many people. The agriculture industry today depends heavily on chemical herbicides and pesticides. Therefore, recommendations against the use of these chemicals demand a sound scientific basis and hence we recommend caution in interpreting such information for the lay public.

In summation, we believe that the cause of IPD is related to environmental factor(s) and those living in rural areas are at a higher risk. The consumption of well water in early life, we believe, predisposes to IPD. Current information indicates that neither metal concentrations in the drinking water, nor the use of paraquat or any other chemical in agriculture, is the cause of IPD. Further studies are necessary to determine the possible environmental cause of this disease.

\section{ACKNOWLEDGEMENTS}

We are grateful to Mrs. P. Basran for her help in continuing studies and to Mrs. L. McPhail in the production of this manuscript. We are indebted to Dr. F.A. Holm of the Department of Crop Science and Plant Ecology, University of Saskatchewan and Dr. J. Iverson of the Veterinary Microbiology Department, University of Saskatchewan for their help in outlining the history of pesticide and herbicide use in Saskatchewan.

\section{REFERENCES}

1. Rajput AH, Offord KP. Beard CM. Kurland LT. Epidemiology of parkinsonism: incidence, classification, and mortality. Ann Neurol 1984; 16: 278-282.

2. Rajput AH, Rozdilsky B, Hornykiewicz O, et al. Reversible druginduced parkinsonism clinicopathologic study of two cases. Arch Neurol 1982; 39: 644-646.

3. Poskanzer DC. Schwab RS. Cohort analysis of Parkinson's syndrome evidence for a single etiology related to sub clinical infection about 1920. J Chronic Dis 1963; 16: 961-973.

4. Duvoisin RC, Eldridge R, Williams A. et al. Twin study of Parkinson's disease. Neurology 1981; 31: 77-80.

5. Ward CD, Duvoisin RC. Ince SE, et al. Parkinson "s disease in 65 pairs of twins and in a set of quadruplets. Neurology 1983; 33: 815-824.

6. Davis GC, Williams AC, Markey SP, et al. Chronic parkinsonism secondary to intravenous injection of meperidine analogues. Psychiat Res 1979: 1: 249-254.

7. Langston JW, Ballard P, Tetrud JW, Irwin I. Chronic parkinsonism in humans due to a product of meperidine-analog synthesis. Science 1983: 219: 979-980.

8. Rajput AH, Elveback LR, Beard CM, Kurland LT. Epidemiology of Parkinson's disease in Rochester, Minnesota. Trans 12th World Congress of Neurology 1981, Kyoto, Japan.

9. Rajput AH. Epidemiology of Parkinson's disease. Can J Neurol Sci 1984: 11: 156-159.

10. Rajput AH, Offord KP, Beard CM, Kurland LT. A case-control study of smoking habits, dementia, and other illnesses in idiopathic Parkinson's disease in Rochester, Minn. Neurol 1986; 36 (Supp l.1): 106
11. Rajput AH, Offord KP, Beard CM. Kurland LT. A case-controlled study of smoking habits, dementia, and other illnesses in idiopathic Parkinson's disease. Neurology (in press).

12. Rajput AH. Juvenile Parkinson's disease response to modern drug treatment. Proceedings of Canadian College of Neuropsychopharmacology, 1983, May 25-27.

13. Rajput AH, Stern W, Christ A. Laverty W. Etiology of Parkinson's disease: environmental factor(s). Neurology. 1984: 34 (Supp I.1): 207.

14. Rajput AH, Uitti RJ, Stern W, Laverty W. Early onset Parkinson's disease in Saskatchewan - environmental considerations for etiology. Can J Neuro Sci 1986: 13: 312-316.

15. Uitti RJ. Rajput AH, Rozdilsky B, Yuen WK. Regional distribution of metals in hurnan brain. Clinical and Investigative Medicine 1985; 8: A158.

16. Uitti RJ, Rajput AH, Rozdilsky B, Yuen, WK. Regional distribution of metals in human brain. Clinical and Investigative Medicine 1986, (in press).

17. Rajput AH, Uitti RJ, O'Donnell D, et al. Metal concentrations in drinking water in Parkinson's disease and controls. Can J Neuro Sci 1986: 13: 185 .

18. Chemical weed control in cereal, oilseed, pulse and forage crops 1986. Saskatchewan Agriculture Bulletin.

19. Wood HE, Olson PJ. A new weed killer 2,4-D. Manitoba Department of Agriculture and Immigration, Publication No. 201 . January, 1946.

20. Calne DB, Langston JW. Aetiology of Parkinson's disease. Lancet 1983; ii: 1457-1459.

21. Haack DG. Baumann RJ. McKean HE, et al. Nicotine exposure and Parkinson's disease. Amer J Epidem 1981: 114: 191-200.

22. Golbe LI, Cody RA, Duvoisin RC. Smoking and Parkinson's disease. Search for a dose-response relationship. Arch Neurol 1986; 43: 774-778.

23. Forno LS, Langston JW, DeLanney LE, et al. Locus ceruleus lesions and eosinophilic inclusions in MPTP-treated monkeys. Ann Neurol 1986; 20: 449-455.

24. Rajput AH, Uitti RJ, Stern W, Laverty W. Relationship between early onset Parkinson's disease and country living. Proceedings of VIII International Symposium on Parkinson's disease. New York, New York, June 9-12, 1985, 49.

25. Barbeau A, Roy M. Genetic susceptibility, environmental factors and Parkinson's disease. Proceedings of the VIII International Symposium on Parkinson's Disease. New York, New York, June 9-12, 1985, 13.

26. Tanner CM. Well water drinking and Parkinson's disease. Proceedings of the VIIIth International Symposium on Parkinson's Disease. New York, New York, June 9-12, 1985, 11.

27. Rosati G, Granieri E, Pinna L, et al. The risk of Parkinson disease in Mediterranean pecople. Neurology 1980; 30: 250-255.

28. Dreosti IE, Smith RM, et al. Neurobiology of the trace elements. Clifton, New Jersey: Humana Press, 1983, Vols 1,2.

29. Rajput AH, Uitti RJ, Rozdilsky B, Yuen WK. Distribution of metals in Parkinson's disease and control brains. Neurology 1985; 35 (Supp 1.1): 224.

30. Barbeau A. Etiology of Parkinson's Disease: A research strategy. Can J Neurol Sci 1984; 11: 24-28.

31. Bocchetta A, Corsini GU. Parkinson's disease and pesticides. Lancet 1986; ii: 1163.

32. Koller WC. Paraquat and Parkinson's disease. Neurology 1986; 36 : 1147.

33. Tanner CM. Influence of Environmental Factors on the Onset of Parkinson's disease (PD). Neurology 1986; 36 (Supp 1.1): 215. 